\title{
Exploring Unique Challenges and Successful Strategies Identified by Black Educators in the Canadian Context
}

\author{
Maureen Finlayson, \\ Teacher Education, Cape Breton University, Canada
}

\begin{abstract}
In today's educational systems, African Canadian educators face unique challenges. This study investigates the perspectives of African Canadians in addressing these challenges. As a Canadian educator for over twenty-five years, and as professional development leader for the African Canadian Services Division of the Nova Scotia Department of Education, I have had conversations regarding the many challenges we face. This presentation will draw on this experience and knowledge. The methodology consists of completing interviews and constructing life histories of ten African Canadian educators at diverse levels in public education in Nova Scotia. The objective is to describe their challenges and successful strategies. Critical factors for success include: financial, family and community support, rigorous academic qualifications, role modeling, caring educators, having someone believe in them, and self-motivation. The author suggests that an improved understanding about African-Canadian educators' lived experiences hold implications for all educators in their teaching approaches and for student learning.
\end{abstract}

\section{Introduction}

In today's educational systems, all educators face many obstacles and challenges. African Canadian educators face unique challenges. This study investigates the challenges and obstacles specific to African Canadian educators in Nova Scotia, a small province on the east coast of Canada, and the strategies which they have identified that have helped them to become successful in their educational careers.

This study was carried out by interviewing ten African Canadian educators in Nova Scotia. Specifically, the purpose of this study was twofold. The first objective was to examine the background and demographic characteristics, early life histories and education, and socio-cultural experiences of ten
African-Canadian educators in Nova Scotia. The second objective was to describe the obstacles and challenges which they have faced, and to discuss the strategies which they have used. Interviews were conducted and life histories were analyzed to describe the complex and multifaceted nature of the experiences of these African-Canadian educators. The voices of these educators provide insights into successful strategies.

\section{Research Rationale}

Teachers of African heritage have been involved in educational struggles for centuries, yet little research exists about African American teachers, and even less about African Canadian educators (Butchart [2]; Graham [12]; Henry [13]).

This reminds us how important it is to have a research focus on the experiences of African Canadian individuals in the everyday world, particularly in the educational context. A close examination of the roles that Black educators, both women and men, serve in the classroom, indicates that Black educators often bring to the classroom experiences, expectations, and teaching methodologies which support and enhance the achievement of Black children. Scholars in this field have documented that teachers are more effective when they provide cultural connections to the curriculum, draw on student cultures in their teaching styles and address the struggles that their students face (Dei [6]; Dickar [7]; Delpit [8]). In their research, Carr \& Klassen reminds us that "the attitude of the teacher is crucial in helping students develop attitudes that will prepare them for a harmonious existence in a society that is culturally diverse" [3:69]. Furthermore, the life histories of teachers represent an exciting, emergent literature that can broaden educational research (Foster [9]; Goodson [11]). I acknowledge the importance of this research with its focus on how a teacher's background and experiences influence the expectations that she/he holds for the students she/he 
teaches (Irvine [14]). I want to contribute to this literature of narrative research by examining the life history and educational experiences of ten Canadian educators of African heritage. It is important to know what challenges they have faced, and what strategies they have created to overcome these challenges and become successful.

\subsection{Research design and goals}

An important feature was the use of the life history method and the choice of participants. The life history method provided a structure to obtain background information, with the flexibility of conversational questions during the interviews. Seidmann [19] has used an interview process to explore the experiences of the participants, their educational experiences and their interactions with members of the communities. This qualitative approach conforms to education research practice and allows the researcher to ask open-ended questions to build upon and explore the participants' responses to these questions.

Interviews were conducted with ten educators of African heritage within the educational school system of Nova Scotia. All indicated a willingness to participate in life history interviews. I have selected these individuals as a result of the leadership positions which they have held at various levels in public education: schools, school boards, and department of education. These individuals represented (a) diverse religious/faith orientations; (b) diverse communities; ( c) families of varying socioeconomic levels and levels of educational attainment; (d) attendance in predominantly minority or majority schools with teachers from diverse races, cultures and backgrounds; (e) educational careers at all levels of public education.

The goal of this research is to have the participant recount her/his experiences within the topic under study. These questions have guided the data collection and analysis:

(1) Describe your family, community, and academic background, and explain what you think in your background has prepared you to be a successful educator?

(2) What obstacles and challenges have you faced?

(3) What strategies have helped you to be successful?

The data collected has been compiled into themes which link the obstacles and challenges faced by the participants, and their strategies to successfully address these challenges.

\section{Participants}

African Canadian educators who participated in this study have been successful. A brief description of each participant follows. As you will see, the participants come from a variety of backgrounds, have had numerous leadership positions in education, and each participant has strong academic qualifications. They all have earned Bachelor of Arts and/or Education; many have Master of Arts and/or Education, and some have a Doctorate in Education or Philosophy. This involved four years, six years or eight years of university education after graduation from high school.

Denise (BA, MEd, DEA) is an African Canadian, who grew up in Barbados. She has taught in schools at many levels for many years, and has been principal of a First Nations school. Denise has always had a desire to teach.

Judith (BA, BEd, MA, MEd) is an African Canadian, born in Nova Scotia. She has taught in schools for many years, and served as Race Relations Cross Cultural Understanding and Human rights $(\mathrm{RCH})$ coordinator for the school board, and acting director of the African Canadian Services Division (ACSD) for the Department of Education of Nova Scotia. Her focus is to address social justice issues.

Andrew (BA, BEd, PhD) is an African Canadian, originally from Uganda. He was selected by his family to pursue university studies, and won the Commonwealth scholarship for Dalhousie in 1985. He has been director of ACSD, and leader in the implementation of the Black Learning Advisory Committee (BLAC) report. Andrew is a strong advocate of encouraging students to have strong academic qualifications.

David (BEd, MEd) is an African Canadian, born in Nova Scotia. David has been supported by his family and community, who places a great deal of expectations on him. He has worked as a teacher, principal, $\mathrm{RCH}$ coordinator, consultant and acting director for ACSD. He often serves as mediator between the African Nova Scotian community and the education system.

Lori (BA) is an African Canadian, born in Nova Scotia. She has served as Coordinator of Scholarships and administration for ACSD. Lori's openness and welcoming approach has provided a crucial role in supporting students, who at times may not have continued and may have chosen to leave their academic studies.

Naomi (BA, BEd, MEd) is an African Canadian, born in Nova Scotia. She has been a teacher, principal of a Community College, and consultant 
and leader in professional development. She has been directly responsible for establishing and implementing policies to support anti-racism education. She is very committed to addressing social justice issues.

Melissa (BA, BEd, MEd) is an African Canadian, born in Nova Scotia. As a single mother, Melissa had to work at several different jobs to survive. She has been a teacher, $\mathrm{RCH}$ coordinator, leader in professional development, and has administered the 4plus program for African Nova Scotian students. Having a strong Christian faith, Melissa spoke proudly of her Baptist church and the emotional support and encouragement which the people of her community have given her throughout her life.

Serena (BA, BEd, MEd) is a African Canadian, born in Nova Scotia, who spoke proudly of her roots. She has been a teacher, an RCH coordinator, a leader in professional development. In this role she advises individuals in the area of program development to incorporate areas of race, gender, sexual orientation, class, etc. into the existing curriculum. Serena believes in treating everyone with respect and dignity.

Ruth (BA, BEd) is an African Canadian, born in Nova Scotia. She says, "I am a teacher because I had people in my life who encouraged me, both in public school and at home to succeed, to live up to my potential". She has taught for many years. In her classes, she incorporates literature of African heritage. Ruth has taken a leadership role in the lead team to develop and implement the curriculum for English 12: African Heritage and African Canadian Studies 11. Ruth insists on students' reaching their potential, in order to have the skills they need to pursue their studies and their dreams.

Sebastian (BA, BEd, MA) is an African Canadian who came to Canada from Zaire in 1981. He has taught for many years in schools, and at the Nova Scotia Teacher's College. His rule of life is to accept himself, to accept others for whom they are, is always open to suggestions to improve his teaching skills. Sebastian is committed to his students and insists on helping his students maximize their language skills in French. Many of his students go on to pursue academic studies in French at university.

\section{Initial Findings}

Based on the data analysis of the life histories, participants identified the following six challenges and nine strategies for success.

\subsection{The Struggle for Survival}

A challenge which many African Canadian educators faced was the struggle for survival. Many of these educators faced financial or socio-economic difficulties. These difficulties refer to parents having limited education, struggling every day to try to pay the bills, to provide food and shelter for their families. The African Canadian educators often had jobs, to make money to pay for their tuition and living expenses, or to support extended family; yet, they were able to achieve academically.

\subsection{The Lack of Encouragement}

As students, another obstacle was the lack of encouragement by advisors at schools. When they were students, many African Canadian educators were advised by some guidance counselors and teachers not to pursue academic courses. David indicated that he was told in grade eight that he was not capable of becoming a teacher or of being successful at university. James [15] wrote of this lack of support by his guidance counselors. When he inquired about pursuing medicine as a career, he was encouraged to consider physical education studies at university. Judith was advised by her guidance counselor to take high school courses which would not allow her to enter academic programs at university; rather the courses would lead her to graduate or to go to a community college or to a secretarial program, resulting in a low paying job.

\subsection{Racism}

Racism is an obstacle that all of these African Canadian educators spoke about. As students, these African Canadian educators encountered racism in several ways: negative stereotypes, being called inappropriate names, being invisible, not receiving support from some teachers or being accused by some educators of being lazy, and not wanting to achieve academically. These examples are reinforced by Codjoe [4] who speaks of the persistence of racism and the schooling experience of Black students in Canada. Melissa spoke about being made fun of by other students because of the color of her skin. At university, Andrew explained that when he would meet some professors, some would look the other way, some would ignore him, others would put their heads down and pretend not to hear him, or just walk by without speaking. In another instance, Judith was asked by a professor at university if she had been accepted in the program not on her academic achievements, but as part of the access program which gave students without the academic average the opportunity to go to university.

Racism sometimes occurred at job interviews. When going for a job interview, Melissa encountered rejection. As she entered the room, and put out her hand to shake hands, no one would shake hands with 
her. Melissa also told of an incident when her mother, who was highly skilled and educated, went for a job interview, she was told to go to the back of the building, and to come in from there, because the accepted practice was that Black people came in from the back of the building.

Racism occurred when they became educators. In some cases, their students would refuse to do what they asked, stating that they did not want a Black teacher. In other cases, students told them that they were lucky to have jobs, and they received these jobs, because they were minorities, or they were of African heritage, or because of the father's status in the community. At meetings, several educators indicated that when they raised points or made suggestions, often these were overlooked, only to be raised later by a White colleague, and then acknowledged as a good idea. Often, in meetings, Juidth, Serena, Naomi, and Melissa indicated that the topic of equity and race relations was always placed at the end of the agenda; or requests for funding and support for race relations were often denied or not even acknowledged. Racism was found in staff rooms. Sometimes teachers would make negative stereotypical comments about Black students.

\subsection{The Lack of Opportunities}

All too often, opportunities for advancement were not available as they were for their White colleagues, with the same qualifications. Although there are some African Canadian educators in schools in Nova Scotia, and a few principals, there are no program directors or superintendents at the School Board level or at the Department of Education level. There are educational consultants, but these positions are often with the African Canadian Services Division at the Department of Education, or in Race Relations and Cross Cultural Understanding at the School Board level.

\subsection{Isolation}

Another obstacle was the isolation. All the educators spoke about frequently being the only Black person at a school, at a meeting, at an event, etc. Naomi, Melissa, Serena, and Ruth indicated that they each felt very alone and isolated at times. If anything emerged regarding concerns or issues linked to African heritage, people from mainstream society would turn to them individually and expect them to know it all, to have all the answers, and to represent all Black persons. Frequently, African Canadian educators indicated that they would not be included in the decision-making, planning and organizing of events, but be expected to attend and participate in the mundane tasks. At times their suggestions and opinions were not recognized; in fact, they felt very invisible.

\subsection{The Curriculum}

Another concern was raised about the curriculum in schools in Nova Scotia. In the curriculum for all subject areas, there was little mention and more frequently no mention of any contributions of individuals of African heritage. When Andrew, who was the Director of the African Canadian Services Division, first took on this role, he was shocked at the lack of Black leaders in the resources. He indicated that when he went into schools or public places of education that he saw no posters, murals, or environments with Black faces. He asked: What does this mean for a Black student? It gives a strong message that Black students are not included, do not belong. When students don't see Black leaders whether in education, in business, in politics, in employment, they don't see these positions as possibilities for them to achieve. Including Black faces in the materials and resources of the curriculum of the public schools on Nova Scotia proved to be a real challenge.

\section{Strategies for Success}

To address these obstacles and challenges, these African Canadian educators used a variety of strategies. There were linked to institutional and financial support, family and community support; personal well-being; having a positive attitude and determination to succeed, academic achievement, and addressing racism.

\subsection{Institutional and Financial Support}

An important strategy to address financial needs was through institutional support. The African Canadian Services Division of the Nova Scotia Department of Education provided scholarship funds for students to continue their academic studies at university. Lori, who was responsible for managing these scholarship applications shared how she often received emails from recipients, who had completed their Master or Doctorate degrees, indicating that the scholarships had made their success possible. These funds, as well as professional development funds, provided on-going support for their educational careers. For all educators, having employers who were supportive of their work and their pursuit of further studies was an essential strategy.

\subsection{Academic \& Professional Qualifications}

Having strong academic qualifications is an 
important part of this institutional strategy. When an opportunity arose, if the African Canadian educator had the skills and required certificates and qualifications, then she or he could apply. Another strategy mentioned was the importance of keeping up to date on all the latest issues. Being up to date in technology was a challenge for many educators. Yet, they felt that this was extremely important, because it provided a way for them to connect with young people, who exhibited a great deal of knowledge and skills in technology.

\subsection{Having a Positive Attitude}

A positive attitude and world view was an important strategy. David and Andrew spoke of how they would sometimes meet members of the African community who were very angry. They explained how finding ways to address this anger was necessary before individuals could develop their potential and take the opportunities provided to them. To be successful, all educators spoke of their determination to succeed, and their refusal to give up when challenges seem to be too overwhelming.

\subsection{Networking}

Another strategy linked to institutions was to find ways to know how the system works. It is important to know the rules and to learn how to move one's ideas forward. When some educators found that their ideas and suggestions weren't acknowledged, they made allies with other colleagues, and had these colleagues move forward their ideas. An important strategy was that of forming a network of co-workers, colleagues, and friends. David explained that when difficulties arose or when he just needed to vent and to talk, having this relationship gave him a place he could go to, and talk openly, without having to explain what he meant. Judith and Ruth knew that if anything surfaced that upset them and which they needed to discuss, their co-workers both from the Black community and the White community were open to listen to them and to provide support. Sebasstian spoke of the importance of creating a team of individuals with whom you could get along, and who would work together to get the work done. Along with this strategy is the importance of being open minded, accepting new ideas, and welcoming new people who join the team. Serena and Melissa identified like minded people who had a passion for social justice, race relations, and cross cultural understanding, at different levels: school, school board and department of education.

\subsection{Family and Community Support}

A strategy mentioned by all the African Canadian educators was the support they received from family members and from the Black community. Many educators had family members or older women, who were willing to share their wisdom and expertise. In one case, the person spoke of the doors which had been opened for her by family members. Judith referred to one sister as a trailblazer, who was a tremendous model for her; another sister, who was calm and meditative, provided her with ways of coping. Sebastian recalled the words of his parents, when things got tough and he was tempted to drop out, "No, no, you can do it, you have to keep going". Support from family, and in particular from the mother, has been quoted as crucial to success in education research. Lynn [16] indicated that his mother provided the nurturing and reassurance that helped him stay grounded. She was there to listen to him and to provide understanding and support during the hardest times.

All educators indicated how when things became difficult, they could go to members of the Black community, who would listen to them and understand, and would give them advice and suggestions on how to cope. David spoke of the importance of having an older person from the Black community as a mentor, with whom he could connect, and he could learn from. He also spoke of the importance of participating in community organizations, such as the Black Educators Association, a place where people understand what he is going through; a place to have conversations and to be involved with groups that strengthen a positive image of being an African Nova Scotian male, in terms of identity development, mental health; of being comfortable with whom he is, and of not buying into negative stereotypes laid upon him by mainstream society.

\subsection{Role Models}

Role models were identified by all the participants. Role models were considered both as mentors for the participants and by the manner in which these African Canadian educators were role models for the students they taught.

Participants spoke about parents, siblings, extended family members, community leaders, teachers, and administrators who were role models for them. Judith spoke about how her mother, who did not have access to public education because of her race, now volunteered as a community leader, and provided the support for all her children to access university educations. Judith's father served 
in public office representing the needs of the Black community in which he lived and ensuring that public education was accessible to all members of the Black community. Both Andrew and David mentioned their grandmothers who had played major roles in their success. Andrew's grandmother would walk $20 \mathrm{~km}$ to speak to his father and insist that his father send Andrew to school. David's grandmother, who had been a teacher and community leader was always there to encourage David when things became difficult for him. Denise talked about her mother as role model, providing a home, and taking on outside work whenever she could, to be able to give Denise the opportunity she needed to become a teacher. Denise's mother strongly felt that education was a way to get out of the poverty cycle.

Andrew spoke proudly of his family and extended family as role models and support of his achievements. He spoke of his uncles who were teachers and role models for him. Andrew's family was poor; they lived on a family farm and grew their own food. Andrew identified an elementary principal who acknowledged his capabilities and contacted his uncle, who represented his father, who had very little formal education. This principal told his uncle to go to his father and tell him to sell what he had, to be able to send Andrew to higher education.

These African Canadian educators identified the importance for them of being role models for their students. When teaching, David would create opportunities in the discussions, projects, and assignments for Black students to learn about their ancestry and their race so that they would feel positive about being African Nova Scotian. In their research, McCray et al., emphasized their belief that Black students need role models if they are to succeed in school. They stated, "Black children need to see more of our faces every day... Seeing a Black teacher may let some child know that Black people are not just doing something negative" [17:287]. Judith believed in creating relationships with her students; she would get to know them, their strengths and skills; she would help them build on their strengths and encourage them. Both Denise and Judith would often spoke to their students about their plans after graduation; and offered support, whether in making contacts for them, in offering references, or in encouraging them to take academic courses so they would have the necessary requirements for applying to academic programs in university.

Andrew was a role model by showing his students that he cared about them. Andrew believed that students don't care what you know until they know that you care about them and have a genuine interest in their success. Andrew would often pair stronger students with weaker students to provide the support they needed to be successful. Andrew believed that individuals aspire to a role or profession where they see somebody they admire; but, to aspire to a position, you need to see someone who looks like you in that role. Andrew understood the importance of having students interact with Black leaders in a variety of positions in education and employment. Andrew also felt that Black teachers could be a role model for other teachers, showing how they can be successful with students of all backgrounds, and sharing their strategies with them.

Ruth and Sebastian were advocates for Black students, especially when they encountered discrimination in other areas in schools. They were role models in that Black students knew that they could come and talk openly to either Ruth or Sebastian, and they would be listened to. Ruth and Sebastian would address racism and discrimination on behalf of their students. However, both Ruth and Sebastian advised students to stay in the classes so they could be successful and graduate from high school.

\subsection{Re-focusing}

A strategy which helped all these educators was leaning on their spiritual resources. Serena indicated that when she would get upset, she would go to her inner self to find peace and self-control. Naomi spoke about the importance of meditation and reflection, taking the time each day to ground herself; thereby, being able to draw on this strength Many African Canadian educators found that the Church was an important strategy for them. Historically, the survival of African Canadians depended on the Church as an institution. It was a way to provide people with hope that there is a higher power than their oppressors. By praying to a higher power, people knew that they were being listened to by someone who is more powerful and who cares, and who would give them strength to continue to survive.

Other ways to re-focus included: belonging to a book club, discussion group or support group, meeting with family and friends. Some volunteered with organizations or churches; some worked with young peoples' groups. Others took time to be by themselves, to reflect, to read, contemplate, and to consider different ways to address what they were dealing with. If things became too stressful, sometimes, the educator would take a couple of days off just to get away from all the challenges and confrontations. All indicated that each of them needed someone with whom they could share all this, let it all out so to speak, and then move on.

\subsection{Addressing Racism}


Racism was addressed at the institutional level and at the personal level. All African Canadian educators agreed that an important way to address racism was through education. By this, they meant that achieving academically was important for Black learners, to empower them, and to give them the self-confidence and skills to address racism whenever it surfaced. Education was equally important for White learners to enable them to understand the pain and suffering that racism causes, and also to become aware of the positive contributions made by of Black members of society.

In the early 1990's, the Black Learners Advisory Committee (BLAC) was formed and consisted of leaders from Black communities in Nova Scotia. This committee travelled around Nova Scotia, interviewed members of the fifty Black communities, had meetings and discussions with them and produced the BLAC report [1]. This report had more than 50 recommendations which were presented and received by the government of Nova Scotia. The BLAC emphasized that the educational system was the place to start with, to address the many concerns raised by members of the Black communities. The Nova Scotia government responded by providing the financial and institutional support to carry out the recommendations.

An important recommendation was the creation of the Council of African Canadian Education (CACE) and the establishment of the African Canadian Services Division in 1996 by the Department of Education of Nova Scotia. This division consisted of a Director, an Assistant Director, an Adult Education consultant, a Student Services consultant, a Curriculum consultant and several support staff. The Director sat at the decision-making table with the other directors of the Department of Education to ensure that the concerns of the Black community were voiced. He managed the finances for his division and established a scholarship fund to provide financial support for students entering university. The Adult Education consultant met with Black community members and discussed with them issues which were important to them. As many members of the Black community had left school early or had lacked the support they had needed to graduate from high school, he provided opportunities for them to complete their education or to receive training or courses so they could become part of the work force. The Student Services consultant worked with students to provide the support they needed to stay in school, and with parents to help them support their children's education. The Curriculum consultant developed curriculum with an African heritage focus.

At the school board level, Race Relations Cross Cultural Understanding and Human Rights ( $\mathrm{RCH})$ coordinators were hired. They addressed racism at the school board level and in schools. When issues arose in schools, the RCH coordinator would be called in to deal with the racism. They also were members of the program committees ensuring that African heritage was incorporated into the curriculum in the classroom.

At the school level, student support workers were hired. They assisted students who were struggling with various subjects. They often served as a liaison between the parents and administration, supporting students in whatever way they could. A 4Plus program was established to prepare four year old children for school.

On a personal level, African Canadian educators addressed racism when it arose. When a racist comment had been made, Naomi responded, "do you realize that this is very insulting and has a negative impact on individuals of African descent". This educator indicated that frequently the person making the comment would apologize, and thank her for bringing this to her attention. Andrew stated that there will be racism whether you like it or not, because there will always be some people with power over others. He believed in the power of moral persuasion, that is "shaming people in power to do the right thing". He would address racism, and say, "what you are doing is not right". Sebastian spoke of the importance of building relationships with colleagues, having them get to know him as a friend and professional. This eliminated racism for him in many ways. All educators spoke about the importance of education, of having African heritage as part of all courses, and of providing students with the opportunity to become aware of the positive contributions of individuals of African descent to community and society. Judith explained how she often suggested to teachers from mainstream society to attend professional development days on topics of African heritage, diversity, racial equity, etc

\subsection{Developing African Heritage curriculum}

With regard to the lack of African heritage in the curriculum, the African Canadian Services Division of the Nova Scotia Department of Education responded by insisting that African heritage be incorporated into the curriculum, to be part of the educational year, and not be limited to one month, African Heritage month. African Heritage resources were purchased and placed in schools across Nova Scotia. The Curriculum consultant played a major role in the evaluation of resources, ensuring that materials with negative stereotypes and graphics would be rejected from the Authorized Learning List of resources. This is supported in research literature where Black educators enriched the curriculum with 
cultural and cognitive strategies that led to greater success for Black students. In his research, Solomon reminds us that "Black educators made sure that curriculum materials reflected a multicultural and antiracist perspective, searched for learning materials with diverse representation, and screened for stereotypes and bias" [20:403].

Two African Heritage courses were created for high school students. An African Heritage literature course was developed as an elective. The resources were purchased and placed in schools. When this course did not receive the enrolment it should have, the course was converted to English 12: African Heritage language arts [5], and could be selected as the required English 12 language arts to replace the traditional English course. A team of 12 teachers from across the province became the lead team, to develop the course and select the resources. Professional development sessions were attended by teachers, principals, guidance counselors at a variety of locations across Nova Scotia. This course became very popular and provided a strong base for developing knowledge of African heritage in the public school system. A second course, African Canadian Studies 11 [5] was developed. A publisher was contacted and a textbook, entitled Black History: Africa, the Caribbean and the Americas [18] was created for this course, as well as a teacher's guide. Teachers were involved in the development of the textbook and the training provided to other teachers. This course was taught in 96 classes in 2009 in Nova Scotia. Both of these courses provided the history and contributions of individuals of African heritage.

\section{Conclusion}

Many experiences and stories of African Canadian educators remain untold. These stories need to be researched and analyzed. For many readers, the perspectives of these ten African Canadian educators might be a first glimpse at interpretive studies on Black educators. It is time to stop and consider the many strategies which they have identified: financial, institutional, and community support; the importance of strong academic qualifications; the inclusion of African heritage in our curricula, the importance of creating strong networks to work together to address the many challenges we face in education; the importance of taking the time to reflect, to share and to move forward with a positive attitude and a determination to succeed, and the strategies to address racism.
Inquiries that focus on how African Canadian educators understand their world and how they live within its contradictions are rarely the foci of educational research. All too often the specific concerns and needs of Black educators, and in particular, of African Canadian educators, are completely overlooked. We need new questions and new starting points. We need inquiries filled with the lived experiences of actual men and women speaking of and in the actualities of their everyday lives. We need to be examining the obstacles and challenges identified by these African Canadian educators, and to begin to consider their implications for all educators. We need to consider how their strategies for success can impact upon all educators and we need to learn from these shared experiences. It is important for all students, and in particular for African Canadian students to hear these stories, to know that there are African Canadian educators who have paved the way for them. A critical focus is to ask questions about how race and class are embedded into the social, academic and emotional experiences of all educators. As researchers, we need to be creating the opportunities for what Foucault describes as the "emergence of subjugated knowledges" [10:84].

\section{References}

[1] Black Learners' Advisory Report. (1974) Halifax, Nova Scotia: Department of Education of Nova Scotia.

[2] Butchart, R. (1998) 'Outthinking and outflanking the owners of the world: a historiography of the African American struggle for education', History of Education Quarterly, 28 (3), 333-336.

[3] Carr, P.R., T.R. Klassen. (1997) 'Different perceptions of race in education: racial minority and White teachers', Canadian Journal of Education, 22(1), 67-81.

[4] Codjoe, H.M. (2001) 'Fighting a 'public enemy' of Black academic achievement - the persistence of racism and the schooling experience of Black students in Canada', Race Ethnicity and Education, 4 (4), 343-375.

[5] Curriculum document (2009) African Canadian Studies 11 Curriculum Document. Halifax, Canada: Nova Scotia: Department of Education of Nova Scotia, 1- 82.; Curriculum document (2008) English 12: African Heritage Curriculum Document. Halifax, Canada Nova Scotia: Department of Education of Nova Scotia, 1-81.

[6] Dei, G.J.S. (1993) 'The challenges of anti-racist education in Canada', Canadian Ethic Studies, 25 (2), 3651. 
[7] Dickar, M. (2008) 'Hearing the silenced dialogue: an examination of the impact of teacher race on their experiences', Race Ethnicity and Education, 11 (2), 115132.

[8] Delpit, L. (1995) Other people's children: Cultural conflict in the classroom. New York: New York Press.

[9] Foster, M. (1994) 'Educating for competence in community and culture: Exploring the views of exemplary African American teachers', in M.J. Shujaa, (ed.), Too much Schooling, too little Education: the Paradox of Black life in White societies. Trenton, NJ: African World Press.

[10] Foucault, M. (1977) 'Power and Knowledge' in C. Gordon, (ed.), Power/Knowledge: Selected interviews and other writings: 1972-1977. New York: Pantheon Books.

[11] Goodson, I. (1992) Studying teachers' lives. New York: Teachers' College Press.

[12] Graham, P.A. (1998) 'Black teachers: a drastically scarce resource', Phi Delta Kappan, 68, 698-705.

[13] Henry, A. (1993) 'Missing: Black selfrepresentation in Canadian educational research', Canadian Journal of Education, 18 (3), 206-222.

[14] Irvine, J.J. (1990) Black students and school failure: Policies, practices and prescriptions. New York: Greenwood.

[15] James, C.E. (2002) 'Achieving desire: narrative of a black male teacher', Qualitative Studies in Education, 15 (2) 171-186.

[16] Lynn, M. (2006) 'Dancing between two world: a portrait of the life of a Black male teacher in south Central LA', International Journal of Qualitative Studies in Education, 19 (2), 221-242.

[17] McCray, A.D. P.T. Sindelar, K.K. Kilgore, L.L.Neal. (2005) 'African-American women's decisions to become teachers: socio cultural perspectives', Qualitative Studies in Education, 15(3), 269-290.

[18] Sadlier, R. et al. (2009) Black History: Africa, the Caribbean and the Americas. Toronto, Canada: Emond Montgomery Publications.

[19] Seidman, I.E. (1991) Interviewing as qualitative research: A guide for researchers in education and the social sciences. New York: Teachers College Press.

[20] Solomon, R.P. (1997) 'Race, role modeling, and representation in teacher education and teaching'. Canadian Journal of Education, 22(4), 395-410. 